\title{
Tongue and tail necrosis in an atypical case of acute steroid responsive meningitis-arteritis in a dog
}

\author{
Tong- en staartnecrose bij een hond met atypische, acute, steroïdresponsieve \\ meningitis-arteritis
}

\author{
${ }^{1}$ S.A.E. Van Meervenne, ${ }^{2}$ J. Declercq, ${ }^{3}$ A. Tipold, ${ }^{4}$ K. Chiers, ${ }^{2}$ I. Van Soens, ${ }^{2}$ B. Van Goethem, \\ ${ }^{2}$ L.M.L. Van Ham \\ ${ }^{1}$ AB LäckebyDjursjukhus, Örntorp 201, 38031 Läckeby, Sweden \\ 2 Department of Small Animal Medicine and Clinical Biology, Faculty of Veterinary \\ Medicine, Ghent University, Salisburylaan 133, 9820 Merelbeke, Belgium \\ ${ }^{3}$ Department of Small Animal Medicine and Surgery, School of Veterinary Medicine Hannover, \\ Buenteweg 9, 30559 Hannover, Germany \\ ${ }^{4}$ Department of Pathology, Bacteriology and Poultry Diseases, Faculty of Veterinary Medicine, Ghent \\ University, Salisburylaan 133, 9820 Merelbeke, Belgium
}

sofie.vanmeervenne@hotmail.com

\begin{abstract}
Acute steroid responsive meningitis-arteritis (SRMA) is a common neurological disorder in young dogs. Typical clinical symptoms of the acute form of SRMA are neck pain, depression and fever. This case report describes a 1.5-year-old Pointer with uncommon neurological deficits (unilateral multiple cranial nerve deficits and Horner's syndrome) and an exceptional necrosis of the tongue. This was believed to be part of the systemic vasculitis accompanying SRMA. The patient also developed tail necrosis and iatrogenic calcinosis cutis, which complicated further treatment of the dog.
\end{abstract}

\section{SAMENVATTING}

Steroïdresponsieve meningitis-arteritis (SRMA) is een vaak voorkomende neurologische aandoening bij jonge honden. Typische klinische symptomen voor de acute vorm van SRMA zijn nekpijn, depressie en koorts. Deze casereport beschrijft een 1,5 jaar oude pointer met zeldzame neurologische symptomen (unilaterale uitval van verschillende craniale zenuwen en Horners syndroom) en een uitzonderlijke necrose van de tong. Het tongletsel was vermoedelijk onderdeel van de systemische vasculitis ten gevolge van SRMA. De behandeling werd verder gecompliceerd door het ontstaan van een staarttopnecrose en iatrogene calcinosis cutis.

\section{INTRODUCTION}

Steroid responsive meningitis-arteritis (SRMA) is a frequently recognized neurological disorder in dogs. The acute form is in most cases characterized by cervical rigidity and pain, pyrexia and polymorphonuclear pleocytosis of the cerebrospinal fluid (CSF) (Tipold and Schatzberg, 2010). SRMA is believed to be an immune mediated disorder, of which the clinical signs result from a combined meningitis and arteritis of the leptomeningeal vessels (Summers et al., 1995). A marked acute phase response supports the hypothesis that SRMA is a systemic disease or that SRMA may be part of the systemic inflammatory response syndrome (SIRS) (Bathen-Noethen et al., 2008). Histopathological studies of this disease in Beagle colonies have shown that vasculitides may not only be found in the central nervous system, but also in several other organs (Felsburg et al., 1992; Snyder et al., 1995; Summers et al., 1995).

This case report describes an unusual case of acute SRMA in a young Pointer. The dog showed additional neurological deficits and developed tongue necrosis early in the disease. This necrosis was suspected to be caused by vasculitis of the tongue vessels, a phenomenon never before described in SRMA.

\section{CASE REPORT}

A 1.5-year-old male German Pointer was presented with anorexia, shivering, weight loss and a stiff, stilted gait. On general clinical examination, the dog was salivating, had fever $\left(40.0^{\circ} \mathrm{C}\right.$; reference range 38.0 $39.0^{\circ} \mathrm{C}$ ) and appeared mildly depressed. He walked with his head down and showed resistance upon manipulation of the head, which was interpreted as neck pain. During neurological examination, mild protrusion of the third eyelid, miosis, ptosis of the upper eyelid, vestibular strabismus, a diminished menace response and a diminished palpebral reflex, all on the right side, were found. These deficits were localized to the sympathetic nerve, the vestibular nerve and the facial nerve on the right side.

Except for leukocytosis $\left(52.3 \times 10^{3} / \mathrm{mm}^{3}\right.$, reference 
range $6-12 \times 10^{3} / \mathrm{mm}^{3}$ ) caused by neutrofilia (3.1 $\times 10^{3} / \mathrm{mm}^{3}$, reference range $\left.0-1.6 \times 10^{3} / \mathrm{mm}^{3}\right)$ and a mild increase in alkaline phosphatase (ALP) (246 U/1, reference range $<123 \mathrm{U} / 1$ ), no other abnormalities were detected on complete blood count and general biochemistry. Coagulation screening tests, including prothrombin time (PTT), activated partial thromboplastin time (APTT), fibrinogen and D-dimers, revealed an elevated fibrinogen value $(607 \mathrm{mg} / \mathrm{dl}$, reference range $100-460 \mathrm{mg} / \mathrm{dl}$ ). Urinalysis showed severe proteinuria $(171.1 \mathrm{mg} / \mathrm{dl}$, reference range $<30$ $\mathrm{mg} / \mathrm{dl}$ ) with a protein-to-creatinine ratio of 1.04 (reference $<0.50$ ).

Computed tomography (CT) of the brain was performed under general anesthesia. Only discrete contrast enhancement around the lateral ventricles was detected.

Cerebrospinal fluid (CSF) analysis obtained from the cerebellomedullary cistern, revealed a pleocytosis of 1024 cells $/ \mu 1$ (reference range $<8$ cells $/ \mu 1$ ), which consisted mainly of toxic neutrophils and showed an increase in protein content up to $524.3 \mathrm{mg} / \mathrm{dl}$ (reference range $10-30 \mathrm{mg} / \mathrm{dl}$ ).

A presumptive diagnosis of bacterial meningoencephalitis (BME) was made. The dog was treated intravenously (IV) with $10 \mathrm{mg} / \mathrm{kg} \mathrm{q} 8 \mathrm{hr}$ amoxicillinclavulanic acid (Augmentin ${ }^{\circledR}$, Glaxo-SmithKline) and $10 \mathrm{mg} / \mathrm{kg}$ q $8 \mathrm{hr}$ metronidazole (Flagyl ${ }^{\circledR}$, Sanofi-Aventis) while waiting for further test results of bacterial culture of CSF, blood and urine, polymerase chain reaction (PCR) for canine distemper virus, Toxoplasma and Neospora and immunoglobulin A (IgA) levels in blood and CSF.

The following day, the rostral part of the tongue was discoloured and paralyzed. A sharply demarcated line appeared and the necrotic part detached (Figure 1).

Because of persisting fever despite antibiotics, a diagnosis of steroid responsive meningitis-arteritis (SRMA) was considered possible and prednisolone (Prednisolone $^{\circledR}$, Kela Laboratoria) was added at a dosage of $0.5 \mathrm{mg} / \mathrm{kg}$ subcutaneously (SC) q $24 \mathrm{hr}$. This resulted in some improvement of the clinical symptoms, but the fever waxed and waned and therefore the antibiotic therapy was changed to cefotaxim (Claforan ${ }^{\circledR}$, Sanofi-Aventis) (20 mg/kg IV q 6 hr). One week later, the fever was still not controlled, so the dosage of prednisolone (Prednisolone ${ }^{\circledR}$, Kela Laboratoria) was increased to $0.5 \mathrm{mg} / \mathrm{kg} \mathrm{SC} \mathrm{q} 12 \mathrm{hr}$, which resulted in complete resolution of the fever.

Bacterial culture of the CSF, blood and urine came back negative. Polymerase chain reaction (PCR) results for canine distemper virus, Toxoplasma and Neospora on blood and CSF were also negative. Immunoglobulin A (IgA) levels in serum and CSF were severely elevated $(366 \mu \mathrm{g} / \mathrm{ml}$, reference range $<100$ $\mu \mathrm{g} / \mathrm{ml}$ and $>3 \mu \mathrm{g} / \mathrm{ml}$, reference range $<0.2 \mu \mathrm{g} / \mathrm{ml}$ respectively). This supported the diagnosis of SRMA and the dog was discharged on prednisolone (Prednisolone ${ }^{\circledR}$, Kela Laboratoria) at a dosage of $0.5 \mathrm{mg} / \mathrm{kg}$ per os (PO) q $12 \mathrm{hr}$. The neurological examination at that time was normal except for partial Horner's syn-

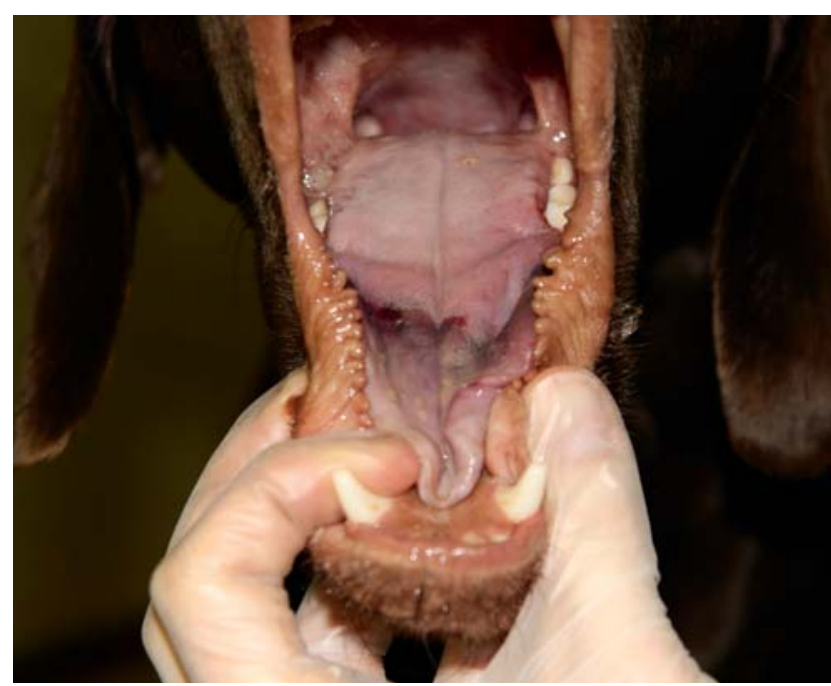

Figure 1. Tongue lesion one day after hospitalization. The cranial part of the tongue is discolored and paralyzed; the border with healthy tissue is sharply demarcated.

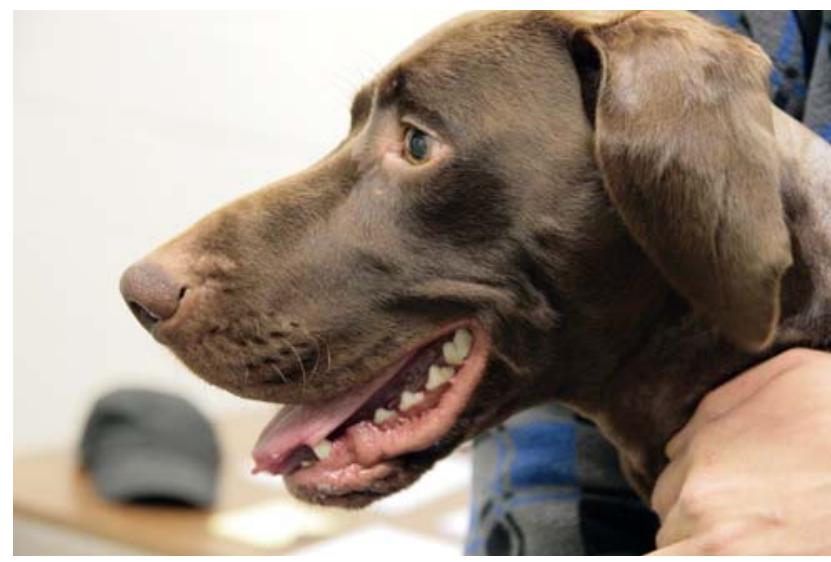

Figure 2. Tongue lesion after four weeks. The tongue wound has healed completely and the tongue functions normally.

drome in the right eye (miosis).

One month after the initial signs, the lesion on the tongue had healed remarkably well (Figure 2), but another skin lesion on the tail of the dog was noticed by the owner (Figure 3). The clinical aspect of the lesion on the tail was consistent with a vasculopathy, such as vasculitis or a thrombo-embolic event. A new coagulation profile was normal. Pentoxifylline (Torental ${ }^{\mathbb{}}$, Sanofi-Aventis) (400 mg PO q 8 hr) was started in addition to the same dose of prednisolone (Prednisolone $^{\circledR}$, Kela Laboratoria).

Another five weeks later, tail amputation was performed as the lesion on the tail top was not healing. Histopathology of the tail lesion showed a chronic reactive process with perivascular infiltration of lymphocytes and plasma cells deep in the dermal layers. Extravasation of red blood cells and degeneration of endothelial cells were signs of a mild vasculitis. At the same time another skin lesion was noticed in the interscapular region. This lesion consisted of thickened and hardened skin, sharply but irregularly demarcated with an intact surface (Figure 4). Histopathology of 


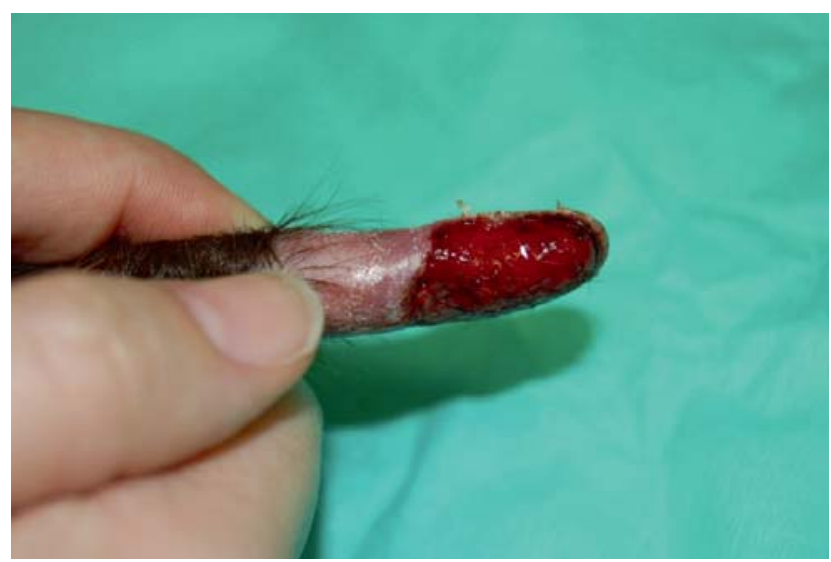

Figure 3. Tail vasculopathy. After removal of the necrotic tissue, a sharply demarcated line is visible between healthy tissue and the lesion.

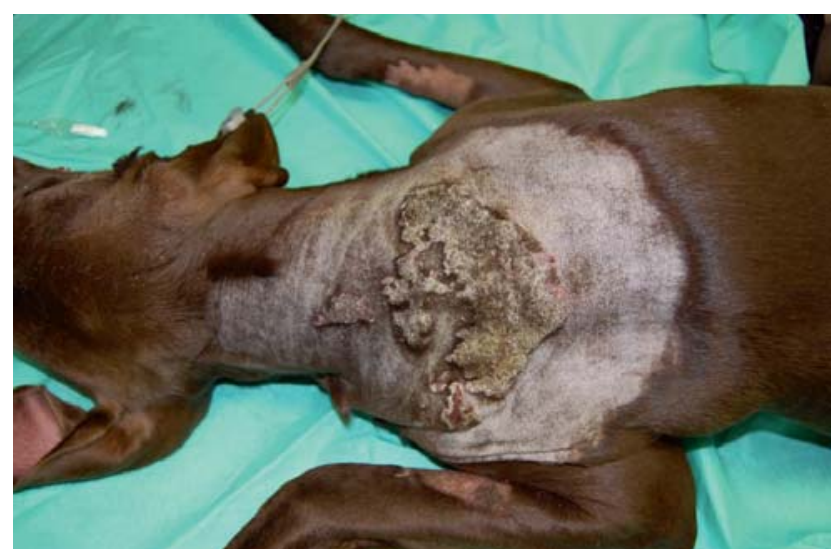

Figure 4. Calcinosis cutis. The skin lesion in the interscapular region consisted of thickened and hardened skin, sharply but irregularly demarcated with an intact surface.

this lesion revealed a diffuse, hyperplastic epidermis with prominent rete ridges. Von Kossa staining showed extensive calcification in the lesion and a diagnosis of calcinosis cutis was concluded. Prednisolone (Prednisolone ${ }^{\circledR}$, Kela Laboratoria) therapy was discontinued as, at that point, CSF analysis showed a normal cell count. IgA levels in serum and CSF were still elevated (respectively $132 \mu \mathrm{g} / \mathrm{ml}$ and $>2 \mu \mathrm{g} / \mathrm{ml}$ ) at that moment. Fever, neck pain and shivering recurred after five days and prednisolone (Prednisolone ${ }^{\circledR}$, Kela Laboratoria) was reinstituted at a lower dosage of 0.25 $\mathrm{mg} / \mathrm{kg}$ PO q $12 \mathrm{hr}$ alternate day therapy.

Two weeks later, the calcinosis cutis was resolving and prednisolone (Prednisolone ${ }^{\circledR}$, Kela Laboratoria) was halved to $0.25 \mathrm{mg} / \mathrm{kg}$ PO q $24 \mathrm{hr}$ alternate day therapy. Prednisolone (Prednisolone ${ }^{\circledR}$, Kela Laboratoria) was slowly tapered and stopped 6 months later. On follow-up 1.5 years later, none of the complaints had recurred.

\section{DISCUSSION}

A young, male Pointer dog was presented with a complaint of acute fever, cervical pain, depressed mental state, right-sided Horner's syndrome and mul- tiple right-sided cranial nerve deficits (facial and vestibular nerve). The lesion was therefore localized in the brainstem or in the peripheral components of the vestibular apparatus with secondary spread to the brainstem. Differential diagnoses for this localization are infectious diseases (BME, canine distemper virus encephalitis, Toxoplasma or Neospora encephalitis, fungal encephalitis, rabies encephalitis and otitis media/interna), inflammatory diseases (SRMA, pyogranulomatous meningoencephalomyelitis of Pointer dogs, meningoencephalitis of unknown origin, eosinophilic meningoencephalitis), intoxication and neoplasia. BME and SRMA were the two main differentials for this patient.

Based upon the presence of mainly toxic neutrophils and the atypical neurological findings (cranial nerve deficits, Horner's syndrome), a presumptive diagnosis of BME was made. The lack of intracellular bacteria in the CSF and a negative CSF culture do not exclude the possibility of BME, since culture results are often (> 80\%) negative (Dewey, 2008). However, no positive response was seen on several antibiotics. The severely elevated IgA levels in serum and CSF and the immediate improvement of clinical signs with the prednisolone therapy were strongly suggestive of the diagnosis of SRMA (Tipold et al., 1994; Tipold and Schatzberg, 2010, Maiolini et al., 2011).

A possible explanation for the cranial nerve deficits in a patient with SRMA is nerve root degeneration secondary to rupture and hemorrhage of the structurally weakened vessels around the cranial nerves. Inflammation of the cranial leptomeninges or choroid plexus is another possible reason for cranial nerve deficits (Tipold and Schatzberg, 2010).

A unique feature in this case was the development of tongue necrosis at an early stage in the disease. Based on the clinical aspect of the lesion, the main differential diagnosis was vasculitis. In SRMA, typical clinical signs result from a combined meningitis and arteritis of leptomeningeal vessels. However, the arteritis may also involve the vessels of the heart, mediastinum and thyroid glands, resulting in a more systemic disease (Snyder et al., 1995; Summers et al., 1995). According to the authors, the involvement of tongue vasculature in a case of SRMA has never been described before. SRMA serves as an animal model for Kawasaki disease and Behçhet disease (Felsburg et al., 1992; Snyder et al., 1995; A. Tipold, personal communication, 2011). Necrosis of the tongue has been reported in both these human forms of systemic vasculitis (Brik et al., 2001; Scardina et al., 2007).

Necrosis of the skin on the tail was also suspected to be due to a vasculopathy, most likely vasculitis. In this case, none of the immunomodulatory drug treatments cured the lesion, hence tail amputation was performed (Weir et al., 1994; Scott et al., 2001). Histopathology of the tail stump reported a chronic reactive process with perivascular infiltration of lymphocytes and plasmacells in the deep dermis. Mild vasculitis was diagnosed based on extravasation of red blood cells and degeneration of endothelial cells. It is 
known that the morphological appearance of arterial lesions in Beagle dogs with SRMA depend on the number of febrile episodes and the duration between the most recent febrile episode and the point at which samples are collected. The vascular lesions in individual dogs represent various stages of inflammation (Snyder et al., 1995). This might explain why only mild vasculitis was detected. Furthermore, the chronic immunomodulatory drug therapy might have influenced the results of the histopathology.

The interscapular skin lesion was diagnosed as calcinosis cutis, probably due to prednisolone use. Iatrogenic hypercortisolism generally results in epidermal atrophy. However, in areas of calcinosis cutis, the epidermis might be acanthotic and exsudative, as also observed in the present case (Gross et al., 2005). The combination of neurological symptoms, skin lesions, the tongue lesion and proteinuria might raise concern about a more complex disease such as systemic lupus erythematosus (SLE). SLE is an autoimmune disorder in which vasculitis is part of the pathogenesis and meningitis may occur in the disease process. However, the most frequent primary complaint of dogs with SLE is a nonerosive polyarthropathy. Although this patient had a stiff, stilted gait at presentation, no swollen joints were detected and therefore, no joint taps were performed. The neurological and dermatological symptoms described in this case were not typical for SLE. The patient had severely elevated IgA levels, whereas it has been described that dogs with decreased serum IgA levels are predisposed to develop SLE (Stone, 2010). Proteinuria due to glomerulonephritis has also been described concurrent to SRMA (Platt, 2004). Because of the presumable diagnosis of BME and SRMA, no further diagnostics for the diagnosis of SLE such as ANA testing were pursued in this patient.

Long-term immunosuppressive glucocorticosteroid therapy is advised in SRMA patients (Cizinauskas et al., 2000; Tipold and Schatzberg, 2010). Because of concerns regarding the wound healing at the moment of tail amputation and the development of iatrogenic calcinosis cutis, prednisolone (Prednisolone ${ }^{\circledR}$, Kela Laboratoria) therapy was discontinued. This decision was supported by a normal cell count in the CSF. IgA levels in CSF and serum were still elevated but these parameters are known to stay high even after remission of the disease, so cell counts and some acute-phase proteins such as C-reactive protein are more reliable to monitor therapy (Cizinauskas et al., 2000; Bathen-Noethen et al., 2008; Lowrie et al., 2009; Tipold and Schatzberg, 2010). Unfortunately, the dog relapsed, furthermore supporting the presumptive diagnosis of SRMA. Immunological processes due to the anesthesia may have complicated the recovery of SRMA in this patient (Cizinauskas et al., 2000).

Long-term glucocorticosteroid treatment in SRMA appears to result only in mild clinical side effects, such as polyuria/polydipsia and polyphagia (Cizinauskas et al., 2000). In this case, none of the typical side effects were noticed, but the dog did develop a localized calci- nosis cutis. This lesion healed despite the continuation of therapy with a lower dose of glucocorticosteroids.

\section{CONCLUSION}

A young dog was presented with some atypical features of acute SRMA (multiple cranial nerve deficits, Horner's syndrome and toxic neutrophils in the CSF). At an early stage in the disease, the dog developed necrosis of the tongue, presumably due to vasculitis. This is the first description of vasculitis of the tongue vasculature as part of this syndrome. Vasculitis of the tongue and of the tail top strengthens the hypothesis that SRMA is a systemic disease. This patient recovered from SRMA with a relatively low dose of glucocorticosteroids, but did develop iatrogenic calcinosis cutis, which healed regardless of continuation of therapy.

\section{REFERENCES}

Bathen-Noethen A., Carlson R., Menzel D., Mischke R., Tipold A. (2008). Concentrations of acute-phase proteins in dogs with steroid responsive meningitis-arteritis. Journal of Veterinary Internal Medicine 22, 1149-1156

Brik R., Shamali H., Bergman R. (2001). Successful thalidomide treatment of severe infantile Behçet disease. Pediatric Dermatology 18, 143-145

Cizinauskas S., Jaggy A., Tipold A. (2000). Long-term treatment of dogs with steroid-responsive meningitis-arteritis: clinical, laboratory and therapeutic results. Journal of Small Animal Practice 41,295-301

Dewey C.W. (2008).Encephalopathies: disorders of the brain. In: Dewey C.W. (editor). A Practical Guide to $\mathrm{Ca}$ nine and Feline Neurology. 2nd Edition, Wiley-Blackwell, Iowa, p. 174-176

Felsburg P.J., HogenEsch H., Somberg R.L., Snyder P.W., Glickman L.T. (1992). Immunologic abnormalities in canine juvenile polyarteritis syndrome: a naturally occurring animal model of Kawasaki disease. Clinical Immunology and Immunopathology 65, 110-118

Gross T.L., Ihrke P.J., Walder E.J., Affolter V.K. (2005). Skin diseases of the dog and cat: clinical and histopathologic diagnosis. Blackwell Scientific Publ.Ltd., Oxford, p 485

Lowrie M., Penderis J., McLaughlin M., Eckersall P.D., Anderson T.J. (2009). Steroid responsive meningitis-arteritis: a prospective study of potential disease markers, prednisolone treatment, and long-term outcome in 20 dogs (2006-2008). Journal of Veterinary Internal Medicine 23, $862-870$

Maiolini A., Carlson R., Schwartz M., Gandini G., Tipold A. (2011). Determination of immunoglobulin A concentrations in the serum and cerebrospinal fluid of dogs: an estimation of its diagnostic value in canine steroid-responsive meningitis-arteritis. The Veterinary Journal, doi: 10.1016/j.tvjl.2010.12.018

Platt S.R. (2004). Neck and back pain. In: Platt S.R., Olby N.J. (editors). BSAVA Manual of Canine and Feline Neurology. $3^{\text {rd }}$ Edition, BSAVA Gloucester, p. 209

ScardinaG.A., Fuca G., Carini F., Velenza V., Spicola M., Procaccianti P., Messina P., Maresi E. (2007). Oral necrotizing microvasculitis in a patient affected by Kawasaki disease. Medicina Oral, Patologia Oral $y$ CirugiaBucal 12, E560-564 
Scott D.W., Miller W.H., Griffin G.E. (2001). Immune-mediated disorders. In: Scott D.W., Miller W.H. and Griffin G.E. (editors).Muller \& Kirk's Small Animal Dermatology. $6^{\text {th }}$ Edition,W.B.Saunders Company, Philadelphia London New York St. Louis Sydney Toronto, p. 742-756

Snyder P.W., Kazacojs E.A., Scott-Monchrief J.C., HogenHesch H., Carlton W.W., Glickman L.T., Felsburg, P.J. (1995). Pathologic features of naturally occurring juvenile polyarteritis in Beagle dogs. Veterinary Pathology 32, 337-345

Stone M. (2010). Systemic lupus erythematosus. In: Ettinger S.J. and Feldman E.C. (editors). Textbook of Veterinary Internal Medicine. $7^{\text {th }}$ Edition, Saunders Elsevier, Canada, p. 783-788

Summers B.A., Cummings J.F., de Lahunta A. (1995). Inflammatory diseases of the central nervous system. In:
Summers B.A., Cummings J.F. and de Lahunta A (editors). Veterinary Neuropathology. $1^{\text {st }}$ Edition, Mosby, St Louis, p.114-116

Tipold A., Pfister H., Zurbriggen A., Vandevelde M. (1994). Intrathecal synthesis of major immunoglobulin classes in inflammatory diseases of the canine CNA. Veterinary Immunology and Immunopathology 42, 149-159

Tipold A., Schatzberg S.J. (2010). An update on steroid responsive meningitis-arteritis. Journal of Small Animal Practice 51, 150-154

Weir J.A.M., Yager J.A., Caswell J.L., Parker W.M., Johnstone I.B., Basrur P.K., Emms C. (1994). Familial cutaneous vasculopathy of German Shepherds: Clinical, genetic and preliminary pathological and immunological studies. Canadian Veterinary Journal 35,763-769

\section{DIERGENEESKUNDIG ONDERWIJS ALS PRIVÉZAAK: LONDEN, 1850}

Het Londense Royal Veterinary College, gesticht in 1791 door de Fransman Vial de Saint-Bel, verschilde van de continentale staatsinstellingen vooral in zijn financiering. Deze gebeurde niet via een staatssubsidie aan een privé-initiatief of een staatsinstelling. Het nodige geld werd bijeengebracht via inschrijving en dit systeem bleef heel lang bestaan. Omstreeks 1850 waren er 125 donateurs die jaarlijks een waarde van 500 Belgische frank van die tijd schonken. Een kleine 800 mensen engageerde zich voor één jaar en schonk ongeveer 50 frank. Ter vergelijking: een ongeschoolde werkman verdiende in die tijd ongeveer één frank per dag. Als tegenprestatie mochten de schenkers hun dieren laten verzorgen in het College, maar ze moesten er toch een kleine vier frank per dag op bijleggen plus de kosten voor de medicamenten. De studenten moesten eveneens 500 frank betalen voor een inschrijving van twee jaar en instaan voor hun eigen levensonderhoud. Bij de op Franse leest geschoeide continentale scholen gold er een streng internaatsysteem vergelijkbaar met dat van militaire scholen of zelfs kazernes.

Zoals het een dergelijke op en top Engelse instelling betaamt, was er een beheerraad onder het hoge patronaatschap van de koningin, toen Victoria. Een lid van de koninklijke familie was voorzitter. De raad bestond verder uit 10 (!) vice-presidenten en 23 (!) bestuurders. De voornaamste leden van deze club behoorden tot de hoge adel. Twee curatoren en één gerant hadden het dagelijkse bestuur in handen.

In tegenstelling tot de beheerraad was het onderwijzend korps karig bemand. Dat bestond uit welgeteld één professor, een adjunct-professor en een lector. De ene al bejaarde prof liet zijn taken grotendeels over aan zijn adjunct, die zelf kon rekenen op de hulp van een prosector ("voorsnijder") die het onderwijs in de anatomie en de pathologie op zich nam.

Tot op heden blijft er iets over van deze achtergrond. Toen het Royal Veterinary College in 1949 aansloot bij de University of London, werd er een federale directie georganiseerd, met enerzijds de universiteit en anderzijds een raad bemand door, onder andere, erfgenamen van talrijke milde (?) voorgangers.

\section{Luc Devriese}

Bron: Douterluigne ainé, Des races chevalines de la Belgique et des institutions hippiques de 1'Europe, Brussel, 1850, p. 145-154. Voor de actuele toestand: de internetsite van het College. 